\title{
On the climate-geometry imbalance, response time and volume-area scaling of an alpine glacier: insights from a 3-D flow model applied to Vadret da Morteratsch, Switzerland
}

\author{
H. ZEKOLLARI, P. HUYBRECHTS
}

\author{
Earth System Science and Departement Geografie, Vrije Universiteit Brussel, Brussels, Belgium \\ Correspondence: H. Zekollari <harry.zekollari@vub.ac.be>
}

\begin{abstract}
A two-dimensional surface mass-balance model is coupled to a three-dimensional higherorder ice flow model to assess the imbalance between climate and glacier geometry for the Morteratsch (Engadine, Switzerland) glacier complex. The climate-geometry imbalance has never been larger than at present, indicating that the temperature increase is faster than the geometry is able to adapt to. We derive response times from transient and steady-state geometries and find that the volume response time is correlated to the magnitude of the mass-balance forcing. It varies between 22 and 43 years, while the length response time is between 47 and 55 years. Subsequently, the modelled response times are compared with different analytical methods from the literature. The effect of a climatic perturbation on the response time, which produces a spatially distributed mass-balance forcing, is also examined. We investigate the effect of glacier size on the response time and project that the response time will decrease in the future due to a surface steepening. Finally, volume-area scaling methods with different parameters are tested and an alternative method is proposed that takes into account the surface slope. The effect of a transient state on the method is also evaluated.
\end{abstract}

KEYWORDS: glacier flow, glacier fluctuations, glacier modelling, mountain glaciers

\section{INTRODUCTION}

Glaciers and ice caps were the main contributors to sealevel rise during the 20th century (Gregory and others, 2013) and also in the 21st century their contribution is projected to be large (Church and others, 2013). However, the mass loss of glaciers in the present century results not only from the additional warming, but is also a consequence of glacier response to the 20th-century warming (Bahr and others, 2009; Marzeion and others, 2014). This is a consequence of the response time, because a change in mass balance takes time to translate into a length and volume change (Cuffey and Paterson, 2010). A better insight into the response time of glaciers is therefore crucial to improve future glacier projections (Zuo and Oerlemans, 1997).

It is, however, difficult to estimate the climate-geometry imbalance and response time of a glacier from observations, as the forcing that glaciers are subjected to changes continuously. Therefore our knowledge of response times relies mainly on analytical methods, conceptual models or numerical experiments with idealized glacier set-ups (e.g. Jóhannesson and others, 1989; Oerlemans, 1989; Harrison and others, 2001; Leysinger Vieli and Gudmundsson, 2004; Raper and Braithwaite, 2009). Explicit modelling studies on individual real glaciers are needed to complement these approaches (Oerlemans and others, 1998). With careful calibration against past changes such studies can provide valuable information about the glacier's present-day state. Interpreting the response time for a real glacier is more complicated than in a conceptual set-up, but is needed to assess the value of the different analytical methods and to better unravel the various processes contributing to the response time of a particular glacier. This is recognized in the analysis of glacier response time by Raper and
Braithwaite (2009), who state that more detailed dynamic flow modelling of individual glaciers is needed for a better understanding. To date, research on the response time of individual glaciers has been limited and based on simple flow models (e.g. Oerlemans, 1988; Huybrechts and others, 1989; Adhikari and others, 2011). Only a few glacier studies have been performed with higher-order $(\mathrm{HO})$ or full-Stokes (FS) three-dimensional (3-D) flow models (e.g. Jouvet and others, 2009, 2011), but these do not focus on the glacier response time.

Here we investigate the climate-geometry imbalance and response time of the well-monitored Morteratsch glacier, Switzerland, by coupling a two-dimensional (2-D) surface mass-balance model to a 3-D HO ice flow model at a high spatial resolution. The modelling relies on an extensive observational dataset and on ice flow and mass-balance models that are calibrated and validated against different sources. This unique set-up allows us to analyse the response time of an alpine glacier in a realistic setting and look at the different factors that influence it, with a particular focus on those that are not taken into account in analytical methods and conceptual models. We start by analysing the present-day (Section 3) and past (Section 4) climate-geometry imbalance. Subsequently, we focus on response time and the effect of the magnitude (Section 5.1) and spatial distribution (Section 5.2) of the forcing, the effects of which hitherto have not been investigated. Response times from our numerical simulations are compared with analytical methods (Section 5.3), and the influence of glacier size is also examined (Section 6). Finally, we discuss the applicability of volume-area scaling (Section 7), suggest how the glacier slope can be incorporated, and analyse the impact of the climategeometry imbalance on this relationship. 


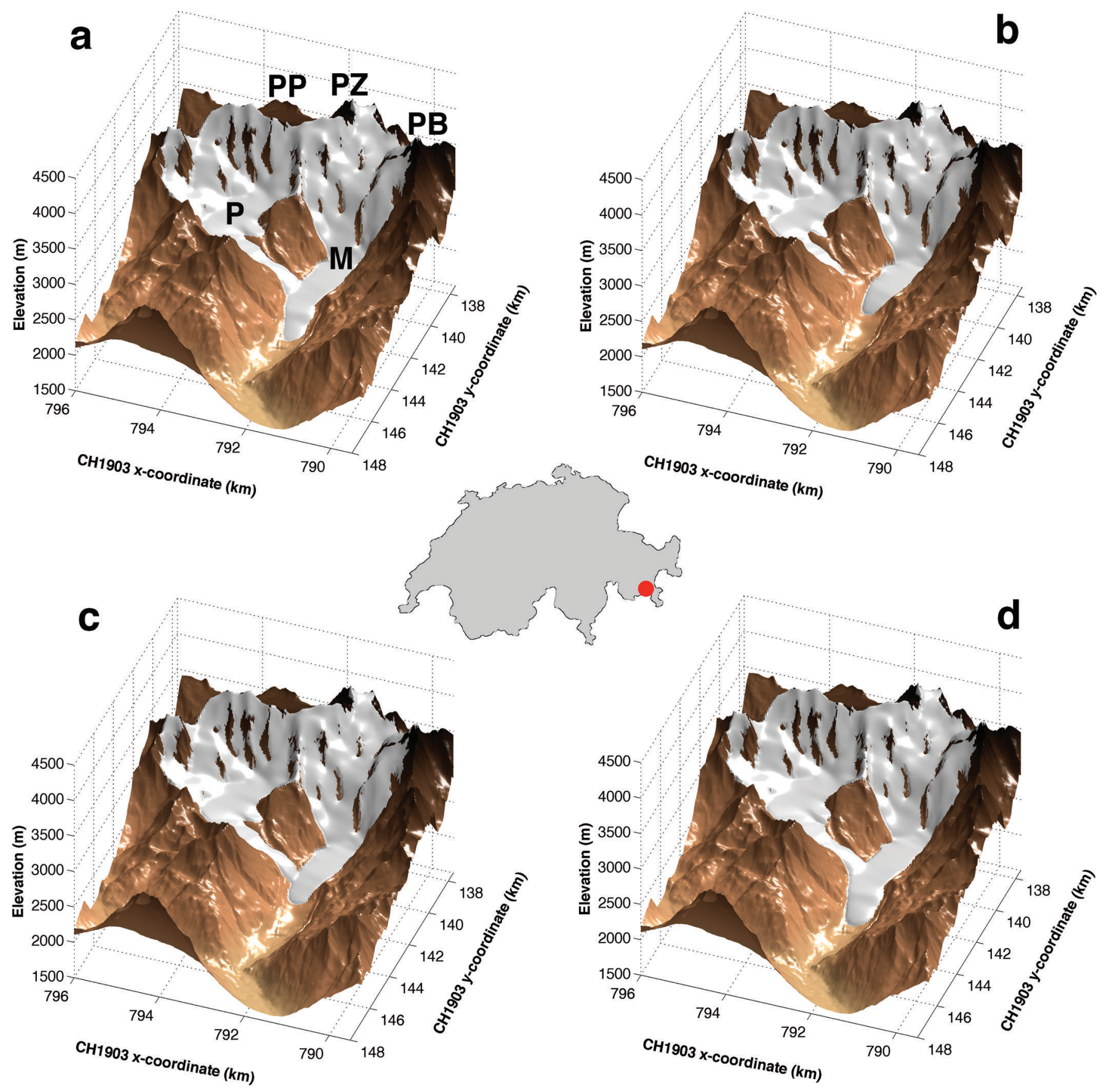

Fig. 1. (a) 2012 transient glacier geometry. The glacier complex consists of Vadret da Morteratsch (M) and Vadret Pers (P). The highest surrounding peaks are Piz Bernina (PB; 4049 m), Piz Zupo (PZ; 3996 m) and Piz Palü (PP; 3905 m). (b) Glacier geometry in equilibrium with the 1983-2012 climate; (c) steady-state glacier with the same volume as the glacier in 2012; and (d) a steady-state glacier with the same length as the glacier in 2012. The red dot on the map of Switzerland indicates the location of Vadret da Morteratsch.

\section{LOCATION, PREVIOUS WORK AND EXPERIMENTAL SET-UP}

The Morteratsch glacier complex is situated in the Engadine, southeastern Switzerland (Fig. 1), and consists of the main Vadret da Morteratsch and its tributary, Vadret Pers. At present (2012), the glacier has a length of $6.3 \mathrm{~km}$, an area of $\sim 16.0 \mathrm{~km}^{2}$ and spans an elevation range between 2100 and $4000 \mathrm{~m}$. Over the last 13 years our research group has collected an elaborate dataset on annual mass balance, ice thickness and surface velocity. These data were used to calibrate a 2-D surface energy-balance model (Nemec and others, 2009), to reconstruct the ice thickness and calibrate a 3-D ice flow model (Zekollari and others, 2013), and to simulate the transient evolution of Morteratsch glacier between 1864 and 2100 (Zekollari and others, 2014). In the latter study, a time-dependent mass-balance correction between 0 and $0.5 \mathrm{mw}$.e. $\mathrm{a}^{-1}$ was required between 1864 and 1960 in order to correctly reproduce the observed retreat (Glaciological Reports, 1881-2009), while the evolution from 1960 to 2010 was validated against topographic and volume changes derived from digital elevation models (Zekollari and others, 2014).

The experiments discussed here to investigate the glacier's response time use the same model set-up and flow parameters as in Zekollari and others (2014). We use a HO glacier flow model of the Blatter/Pattyn type (Blatter, 1995; 

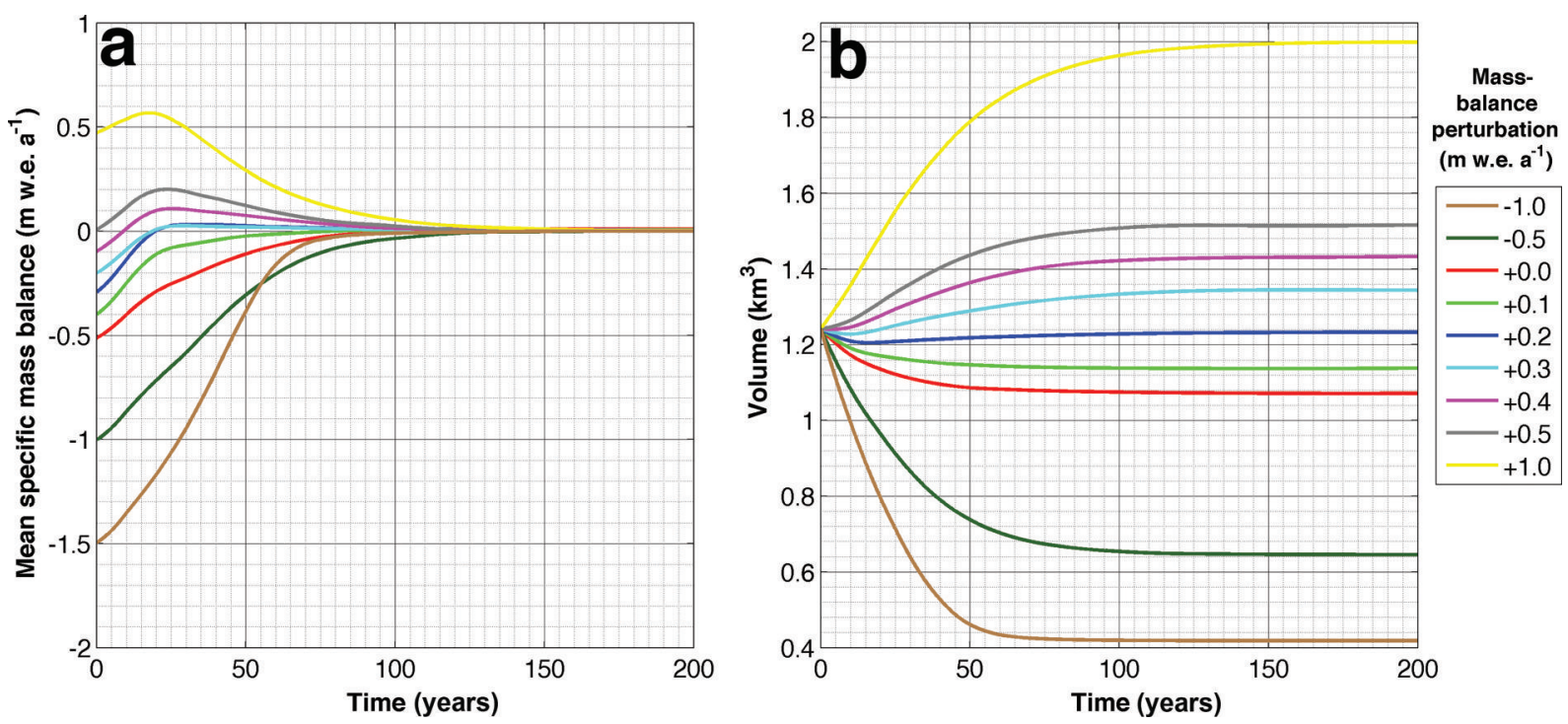

Fig. 2. Evolution of 10 year running mean specific mass balance (a) and volume over the glacier (b) for different mass-balance perturbations versus the 1983-2012 climate. Initial condition of the simulation is the 2012 geometry from a transient simulation.

Pattyn, 2003), with an efficient and more stable finitedifference implementation of the governing equations (Fürst and others, 2011). The horizontal resolution is $25 \mathrm{~m}$ and there are 21 layers in the vertical. The internal deformation is described by Nye's generalization of Glen's flow law (Glen, 1955; Nye, 1957). For basal sliding, a Weertman-type sliding law (Weertman, 1964) is used in which the basal drag corresponds to a $\mathrm{HO}$ approximation of all basal resistive stresses (following Van der Veen and Whillans, 1989). The flow model is coupled to the simple energy-balance model of Nemec and others (2009), which accounts for the shading effect of surrounding mountains and seasonal changes in albedo. The present-day ice-free patches above $3000 \mathrm{~m}$ are explicitly kept ice-free in all simulations, as we know from historical evidence that since the Little Ice Age (LIA) these have never been covered with ice.

In general, the asymptotic approach to a steady state can be described using relatively simple models (Raymond and others, 1990), except for small mass-balance perturbations, where approaches based on the shallow-ice approximation (SIA) can be problematic (Greuell, 1992). Furthermore the presence of basal motion leads to differences in response time between SIA models and more complex flow models, including longitudinal and transverse stress gradients (Gudmundsson, 2003). This justifies the use of a $\mathrm{HO}$ ice flow model in the current study.

\section{PRESENT-DAY STEADY STATE}

\subsection{Forcing with present-day climate}

Morteratsch glacier is strongly out of equilibrium with the climate in which it is situated. Under the 1983-2012 average climate, a mean specific mass balance of -0.55 mw.e. $\mathrm{a}^{-1}$ is obtained for the 2012 transient glacier geometry (Fig. 1a). Using these climatic conditions as an input for the mass-balance model and coupling it to the dynamically calibrated ice flow model leads to a strong retreat of the glacier until a new equilibrium with the imposed climate is reached (Fig. 1b). As the model was extensively tuned and validated for the past, we interpret this retreat as an adaptation to the climate-geometry imbalance and not as an artefact of modelling uncertainties (e.g. uncertainty in bed or flow parameters). The glacier thinning occurs mainly at low elevations, where the glacier adapts to the reduced ice flux divergence similar to other glaciers (Berthier and Vincent, 2012). This leads to a frontal retreat of $1250 \mathrm{~m}$ for Vadret da Morteratsch, while its main tributary, Vadret Pers, disconnects and retreats $500 \mathrm{~m}$ (Fig. 1b). During this retreat the mean specific mass balance evolves to $0 \mathrm{~m}$ w.e. $\mathrm{a}^{-1}$ as expected, which takes $\sim 100$ years (red curve in Fig. 2a). The accumulation-area ratio (AAR) increases from $50 \%$ to $58 \%$, mainly because the glacier has lost part of its tongue area with the highest ablation.

This retreat may be influenced by other factors, such as changes in debris cover and albedo. A debris layer of considerable size has an insulating effect on the glacier surface and leads to reduced ablation. In the likely case of a future extension and thickening of this debris layer, the volume loss and glacier retreat would be attenuated (Jouvet and others, 2011). On the other hand the albedo of exposed ice in the summer is known to decrease due to accumulation of dust from exposed side moraines (Oerlemans and others, 2009). Lowering the ice albedo to 0.25 (from 0.37 in our set-up) leads to an additional frontal retreat of $500 \mathrm{~m}$, and the volume loss increases to $90 \%$, while with an ice albedo of 0.15 the glacier retreats an additional $675 \mathrm{~m}$ and the volume loss increases to $128 \%$.

\subsection{Glacier with present-day length and volume}

In order to obtain steady-state geometries with the 2012 length and volume an ensemble of runs is launched with different mass-balance perturbations compared with the 1983-2012 climatology (Fig. 2). For a steady-state glacier with the 2012 volume $\left(1.24 \mathrm{~km}^{3}\right)$ a mass-balance perturbation of +0.2 m w.e. $\mathrm{a}^{-1}$ on top of the 1983-2012 average climatology mass-balance field is required (Fig. 2b). This corresponds to a precipitation increase of $10 \%$, or alternatively, a temperature decrease of $0.4^{\circ} \mathrm{C}$. Only a small positive perturbation is needed, as little ice volume is present in the glacier's frontal region, where the imbalance is mainly located. The steady-state glacier configuration with the 2012 volume (Fig. 1c) is almost $1 \mathrm{~km}$ shorter than 


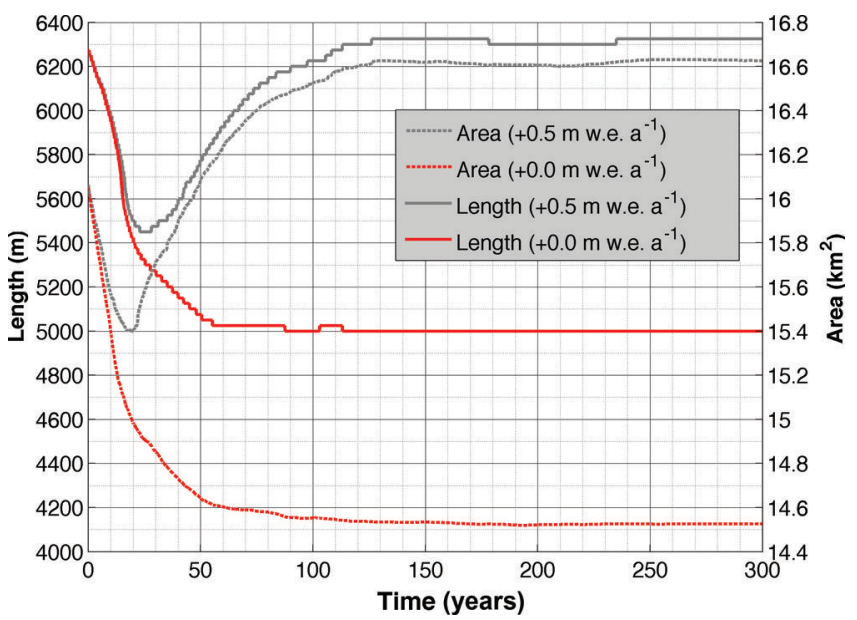

Fig. 3. Evolution of area and glacier length over time while maintaining the 1983-2012 climate (red) and for a mass-balance perturbation of $+0.5 \mathrm{~m}$ w.e. $\mathrm{a}^{-1}$ (grey) compared with this period. Initial condition of the simulation is the modelled transient state of the glacier in 2012.

the 2012 transient glacier (Fig. 1a), mainly because the tongue of the steady-state glacier is thicker than for the retreating transient glacier.

To obtain a steady-state glacier with the 2012 length, on the other hand, a mass-balance perturbation of about $+0.5 \mathrm{~m}$ w.e. $\mathrm{a}^{-1}$ is required (Fig. 3 ), close to the value needed to neutralize the current mass imbalance of $-0.55 \mathrm{~m} \mathrm{w}$.e. $\mathrm{a}^{-1}$. This corresponds to $20-25 \%$ higher precipitation or, alternatively, to a temperature change of $\sim-0.9^{\circ} \mathrm{C}$ compared with the 1983-2012 climate. The resulting glacier (Fig. 1d) has a thicker frontal region than the 2012 transient glacier, which translates into a $22 \%$ larger volume (Fig. 2b). This 'lengthpreservation' experiment illustrates the slow response of the system, as the glacier initially continues to retreat a maximum of $750 \mathrm{~m}$, despite the applied positive massbalance perturbation (Fig. 3). The retreat lasts for almost 25 years, until the effect of the higher flux from upstream becomes dominant and allows the glacier to advance again to its present-day position. This advance results from the increase in mass balance applied at the beginning of the experiment (Fig. 2b). The glacier's slow response is also clear from the evolution of its area, which is almost identical under the constant 1983-2012 climate, and for the 'lengthpreservation' experiment for the first 20 years (Fig. 3). This long reaction time, also referred to as initial terminus response time, fits the characteristics of the glacier at this extent (Pelto and Hedlund, 2001).

The preservation experiments with a strong forcing (-1.0, $-0.5,+0.5$ and +1.0 mw.e. $\mathrm{a}^{-1}$ ) display an exponential volume evolution (Fig. 2b). This evolution is therefore best characterized by its e-folding timescale in which the response time $\left(T_{\mathrm{e}}\right)$ corresponds to the time a glacier needs to complete a fraction $1-\frac{1}{\mathrm{e}}$ (i.e. $63.2 \%$ ) of its final volume change. This formulation of the response time arises naturally from solving a differential equation for glacier volume after applying a stepwise mass-balance perturbation from an initial steady state. However, the latter is not the case here, which has several implications that are discussed in Section 5.1. The volume response times obtained from the preservation experiments vary around 30 years and are shorter for a glacier retreat (24.5 and 30.1 years for -1.0 and

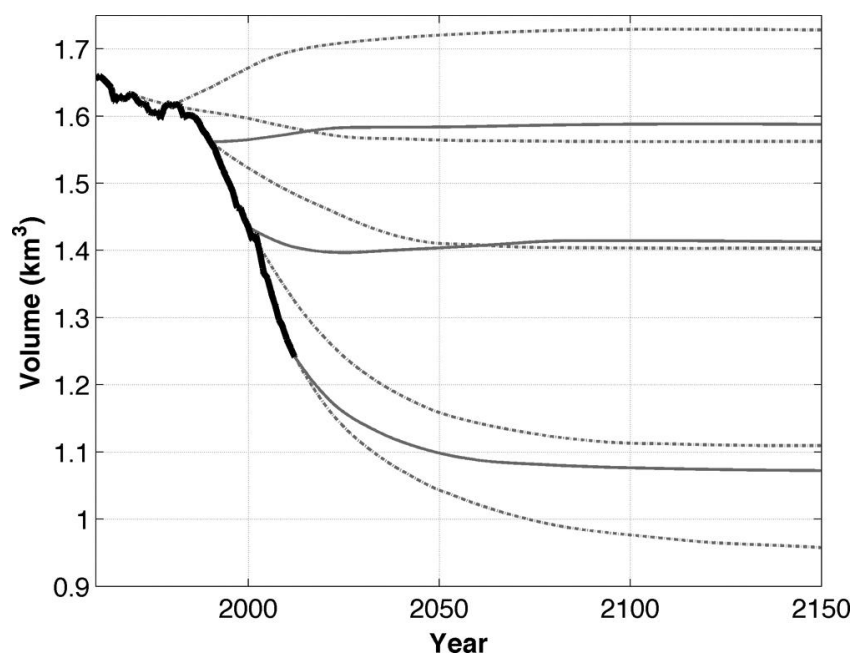

Fig. 4. Evolution of glacier volume when preceding 10 (dashed line) and 30 year (solid line) average climatologies are applied for different moments during the transient evolution. The black line represents the modelled volume evolution between 1960 and 2012 (Zekollari and others, 2014).

$-0.5 \mathrm{~m}$ w.e. $\mathrm{a}^{-1}$ forcing, respectively) than for an advance (43.8 and 41.3 years for +0.5 and $+1.0 \mathrm{~m}$ w.e. $\mathrm{a}^{-1}$ forcing respectively).

\section{QUANTIFYING THE CLIMATE-GEOMETRY DISEQUILIBRIUM IN TIME}

Since the LIA, Morteratsch glacier has been retreating continuously, reducing its length by $\sim 30 \%$ (Glaciological Reports, 1881-2009; Maisch and others, 1999). The disequilibrium between the climate and glacier geometry has changed over time, but due to the glacier's response time the disequilibrium cannot be derived directly from the observed length or volume record. The climate-geometry imbalance is investigated here for different periods in the last 50 years by imposing the mean climate of the preceding 10 or 30 years (Fig. 4). This is conducted from 1970 onwards for the 10 year climatology and from 1990 onwards for the 30 year climatology. Such a procedure is not applicable for an earlier time because until 1960 an additional massbalance bias was required to correctly simulate the historical retreat of the glacier since 1860 (Zekollari and others, 2014).

Over the past half-century, the climate-geometry imbalance has never been larger than at present, since the strongest retreat and volume loss occur for the present-day glacier and climate. Over recent decades the temperature has increased relatively faster than the glacier geometry was able to adapt to the ongoing warming, causing an increased climate-geometry imbalance.

The only time at which the glacier was close to a steady state was in 1990, when the geometry adjusts minimally $(0.2 \%$ area increase) under the 1961-90 climate and the ice volume remains almost the same $(1.6 \%$ increase) (Fig. 4). The period from 1965 to 1975 was the coldest of the last 70 years, causing the glacier retreat to be very limited in the second part of the 1980s and leading to the nearly steadystate situation of 1990 . The time lag between the colder period from 1965 to 1975 and the decreased glacier retreat suggests that the response time of the glacier must be of the order of a few decades. 

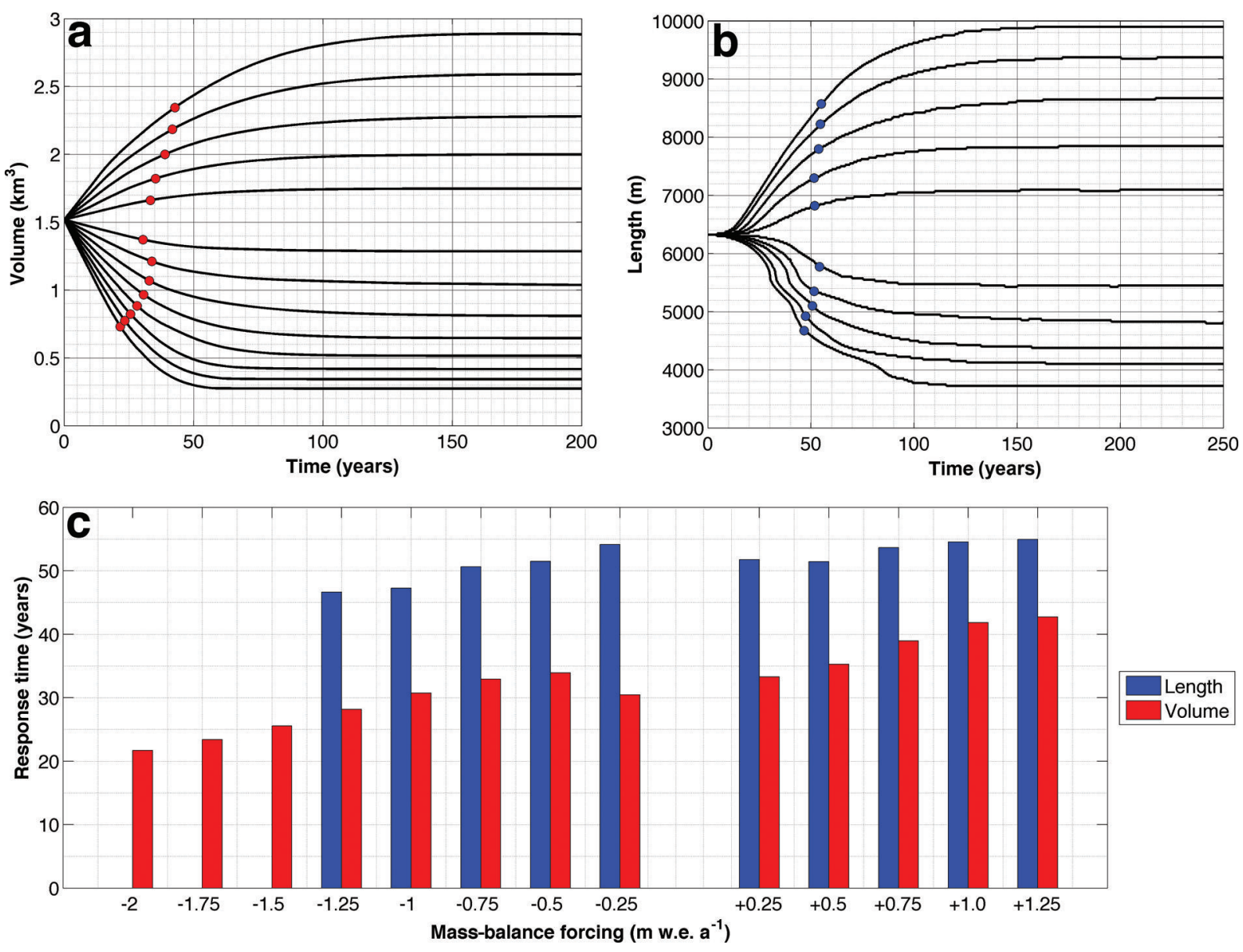

Fig. 5. Evolution of volume (a) and length (b) for different mass-balance perturbations (from -2.0 to $+1.25 \mathrm{~m}^{\mathrm{w}}$.e. $\mathrm{a}^{-1}$, in intervals of $0.25 \mathrm{~m}$ w.e. $\mathrm{a}^{-1}$ ). Initial condition of the simulation is a steady state with the same length as the present-day glacier, obtained by applying a $+0.5 \mathrm{~m}$ w.e. $\mathrm{a}^{-1}$ mass-balance bias on top of the average 1983-2012 climate. This bias is maintained during the simulations. The red and blue dots mark the position where the volume and length response times are reached respectively. (c) Volume and length response time for different mass-balance perturbations. For the three most negative perturbations the length response time could not be determined, as the glacier disintegrates into separate ice patches during its retreat.

\section{GLACIER RESPONSE TIME}

The experiments discussed so far do not allow 'clean' statements to be made about the response time as an initial trend is present. In order to investigate the glacier's response time, the steady-state glacier with present-day length is now used as an initial state.

\subsection{Mass-balance perturbation}

The steady-state glacier is forced with uniform mass-balance perturbations between -2.0 and $+1.25 \mathrm{~m}$ w.e. $\mathrm{a}^{-1}$ at an interval of $0.25 \mathrm{mw}$.e. $\mathrm{a}^{-1}$. These perturbations are applied on top of the initial mass-balance field obtained from the 19832012 climatology, in addition to a uniform +0.5 m w.e. $\mathrm{a}^{-1}$ forcing that is required to obtain an initial glacier with the 2012 length.

\subsubsection{Volume response time}

Volume response times vary between 21.7 (-2.0 m w.e. $\mathrm{a}^{-1}$ forcing) and 42.7 years (+1.25 mw.e. $\mathrm{a}^{-1}$ forcing) (Fig. 5). For a limited glacier retreat (forcing between -0.25 and $-1.0 \mathrm{mw}^{\mathrm{w}} \mathrm{e} . \mathrm{a}^{-1}$ ) there is no clear correlation between the magnitude of the forcing and the volume response time, which varies between 31 and 33 years. As the magnitude of the forcing increases, the final volume loss also increases, but so does the rate at which this volume is lost, and both outweigh each other in terms of volume response time.
For strong negative perturbations (from -1.25 to $-2.0 \mathrm{mw} . \mathrm{e} . \mathrm{a}^{-1}$ ) the present-day ablation area, which contains most of the glacier's ice volume, is lost. For all these experiments there is not much difference in the final volume obtained (Fig. 5a). However, the volume loss rate increases with the magnitude of the perturbation, meaning that the volume response time decreases as the magnitude of the perturbation increases. For the strong negative perturbations it is the specific volume-elevation distribution of Morteratsch glacier that determines its response time.

The relationship between the magnitude of the massbalance perturbation and the response time is different for an advancing glacier. As the magnitude of the forcing increases, the final volume increases relatively faster than the rate of the volume increase (Fig. 5a), and this leads to longer response times. The strong volume increase results from a glacier advance in the very flat glacier forefield, where ice thickness can be up to 200-250 m, similar to the situation at the end of the LIA.

For large perturbations, volume response times derived from the steady-state experiments appear to be close to those derived from the 2012 transient geometry as initial condition (Section 3.2). For the steady-state geometry experiments, the volume response time is 22 years for the $-2.0 \mathrm{mw}^{\mathrm{m}} \mathrm{e} . \mathrm{a}^{-1}$ forcing (vs 20 years for the present-day geometry), 31 years for the $-1.0 \mathrm{mw}$.e. $\mathrm{a}^{-1}$ forcing (vs 25 years), 34 years for 
the $-0.5 \mathrm{~m}$ w.e. $\mathrm{a}^{-1}$ forcing (vs 30 years), 36 years for the $+0.5 \mathrm{mw}$.e. $\mathrm{a}^{-1}$ forcing (vs 44 years) and 42 years for the +1.0 m w.e. $\mathrm{a}^{-1}$ forcing (vs 41 years). Owing to its thinner tongue, the present-day glacier retreat will be faster than for an initial steady state, and its advance slower. Since only little ice volume is present in the frontal region of the present-day glacier, this has an opposite effect on the glacier's response time. For a retreat, the final volume change is smaller for the present-day glacier compared with a steady-state glacier of the same length. The two effects partly outweigh each other, and as a result the volume response times derived directly from the transient glacier geometry are close to those derived from a steady-state glacier of the same length. It is interesting to note that the response time of 32 years derived from the evolution of the mean specific mass balance for the presentday glacier geometry under fixed present-day climate conditions (no-warming experiment) (Zekollari and others, 2014 ) is close to the 34 years obtained here from the steadystate experiments. These findings suggest that for large perturbations the response time of a retreating glacier can be derived directly from its transient geometry.

\subsubsection{Length response time}

The length response time is less well correlated with the magnitude of the perturbation and varies between 47 and 55 years (Fig. 5). The remarkably long length response time for the $-0.25 \mathrm{~m}$ w.e. $\mathrm{a}^{-1}$ experiment relates to the flat bed in front of the glacier, due to which a strong frontal retreat of $900 \mathrm{~m}$ occurs. Length response times (Fig. 5b) are in all cases greater than the volume response times, as the glacier volume reacts immediately (Fig. 5a), while for the length a certain amount of time is needed, the 'initial terminus response time' (Pelto and Hedlund, 2001). The ratio between the length and volume response time varies from $1.29\left(+1.25 \mathrm{~m}\right.$ w.e. $\mathrm{a}^{-1}$ forcing) to $1.65\left(-1.25 \mathrm{mw}\right.$.e. $\mathrm{a}^{-1}$ forcing). This is in line with ratios from other studies based on an idealized glacier geometry: for example, Oerlemans (2001) found a ratio of 1.35 for three simple glacier geometries, while Leysinger Vieli and Gudmundsson (2004) report an average ratio of 1.28 in the case of an advance and 1.46 for a retreat. Only the upper end of our range is higher than the values obtained for idealized glacier geometries, due to the short volume response times we found for the strong negative mass-balance perturbations.

\subsection{Climatic perturbation}

In the literature the response time of a glacier is usually determined from uniform mass-balance perturbations or equilibrium-line altitude (ELA) changes. In reality, however, a glacier is subject to changes in temperature, precipitation and radiation, and the mass balance does not change equally over the glacier. To investigate the effect on the response time, experiments are launched by varying temperature (between $-2.0^{\circ} \mathrm{C}$ and $+3.0^{\circ} \mathrm{C}$ ) and precipitation (from $-50 \%$ to $50 \%$ ) separately. For comparison, for each of these simulations an experiment is launched with a spatially uniform mass-balance perturbation over the glacier that corresponds to the average mass-balance perturbation of the particular climatic forcing.

Temperature changes influence the mass balance mostly in the ablation area of the glacier, both for positive and negative perturbations (Fig. $6 a$ and $b$ ). This is because temperature is a controlling factor for melting, a process that occurs mainly in the ablation area of the glacier, and because there temperature largely determines the rain or snow fraction. For a temperature decrease the glacier advance is stronger than for a uniform mass-balance forcing over the whole glacier. The final glacier volume is larger, leading to longer length and volume response times (Fig. 7). For a temperature increase the glacier retreats and mainly loses ice at low elevation. The remaining ice at higher elevations is exposed to a less negative mass-balance forcing (compared with the spatially uniform mass-balance forcing) and the total volume loss and glacier retreat is more limited, resulting in shorter length and volume response times.

For precipitation changes, the dominant mass-balance change occurs at and above the ELA. However, the spatial contrast between the ablation and accumulation area (Fig. 6c and $\mathrm{d}$ ) is weaker than for the temperature forcing (Fig. 6a and b). For an increase in precipitation the total volume increase and glacier advance are more limited than for a fixed average mass-balance forcing, as for the former the mass-balance increase is confined to the highest areas. This results in slightly shorter response times (Fig. 7). For a precipitation decrease, the area and volume losses are very similar to those for a uniform mass-balance forcing $(<1 \%$ absolute difference), because the forcing is strongest around the ELA and the spatial contrast in mass-balance forcing is small. The response times are longer than for similar uniform massbalance forcings as the final volume change is similar, but the forcing is slightly stronger in the upper areas. This is clear for the $-10 \%$ precipitation forcing (Fig. 7), where the very small mass-balance perturbation initially affects the accumulation area, and the frontal retreat only starts after 32 years.

\subsection{Comparison with other response-time definitions}

\subsubsection{Analytical methods}

In the literature, several analytical methods have been presented to determine the response time of a glacier. Some of the older attempts are based on linear kinematic wave theory (Nye, 1960, 1965) in which the response time is determined as the ratio between the glacier length and the flow velocity at the snout. Applying this to Morteratsch glacier, with a length of $6.3 \mathrm{~km}$ and snout velocities $<20 \mathrm{~m} \mathrm{a}^{-1}$, results in a response time above 300 years. This method, in part due to the difficult definition of the snout velocity, usually leads to strong overestimations (Van de Wal and Oerlemans, 1995). Alternatively, this value can be multiplied by the shape factor, the ratio of the average ice thickness change over the glacier to the change at the front (Jóhannesson and others, 1989; Schwitter and Raymond, 1993). With a shape factor of $\sim 0.2$, the value calculated by Schwitter and Raymond (1993) for Vadret da Morteratsch, this results in a response time above 60 years, still considerably higher than the values obtained from our numerical experiments.

One of the most used analytical methods defines the volume response time as the ratio between the characteristic ice thickness $\left(H_{\text {char }}\right)$ and the mass-balance rate at the snout $\left(b_{\text {snout }}\right)$ (Jóhannesson and others, 1989):

$$
T_{\text {e, Jóh }}=\frac{H_{\text {char }}}{-b_{\text {snout }}}
$$

However, the definition of $H_{\text {char }}$ is not straightforward. Often the maximum ice thickness is chosen (e.g. Pelto and Hedlund, 2001; Hoelzle and others, 2003), but this is not per se representative for the whole glacier. This reservation also applies to Morteratsch glacier where the maximum ice 

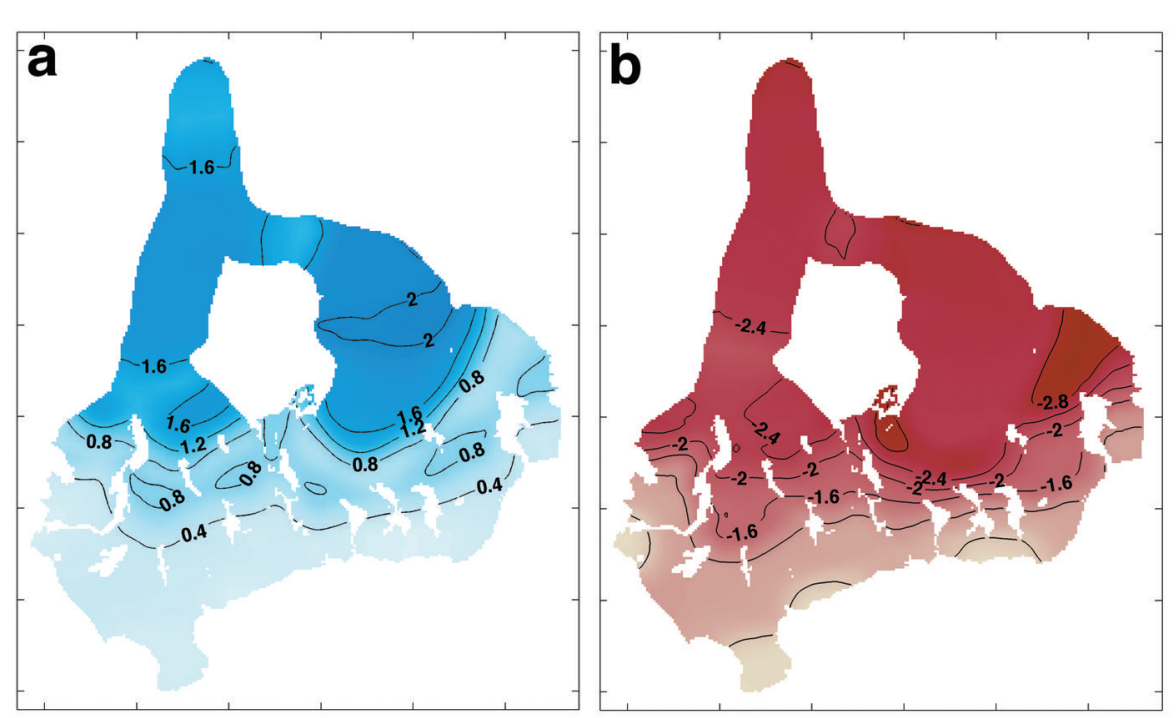

m w.e. $a^{-1}$
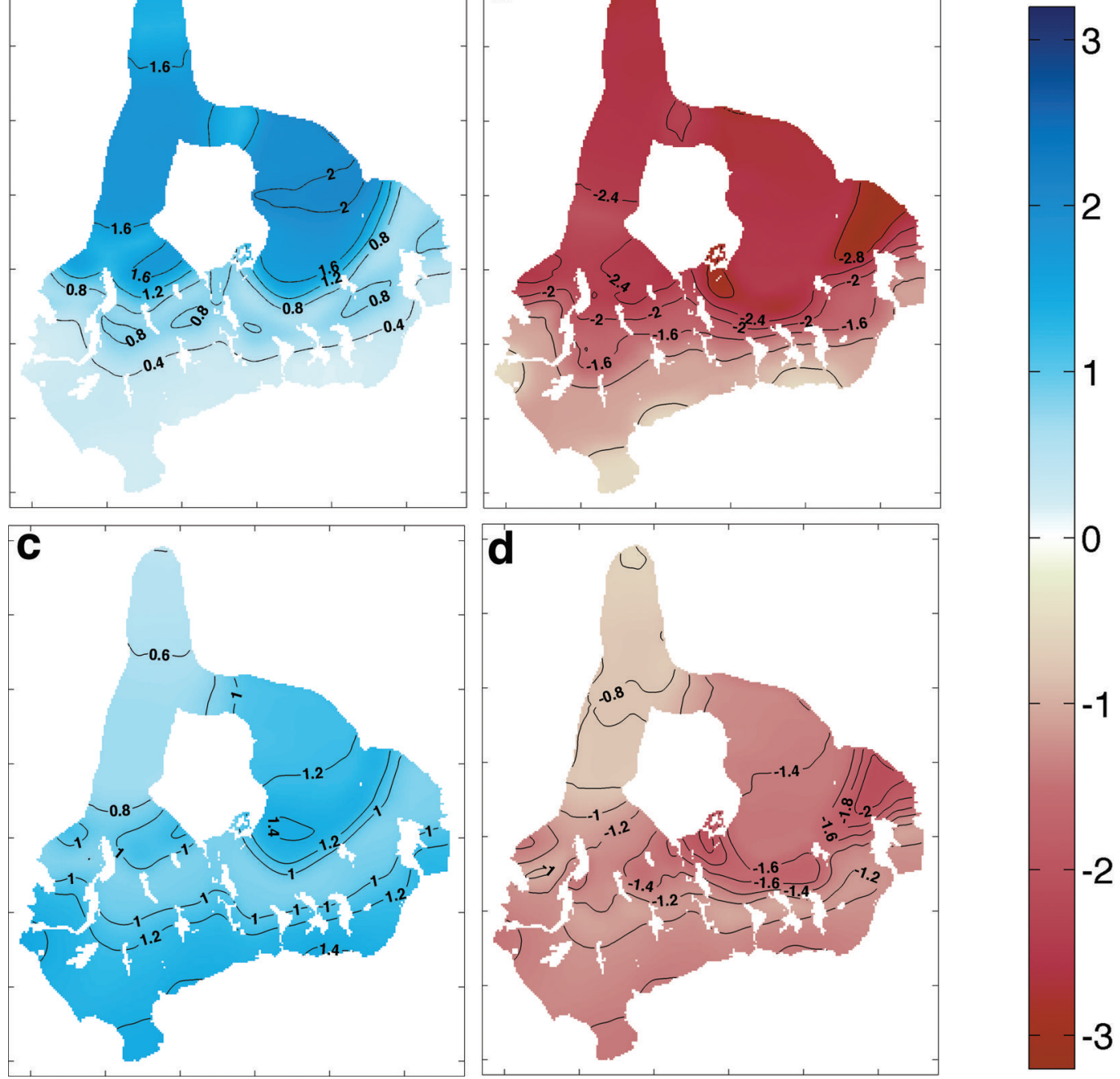

Fig. 6. Spatial mass-balance forcing for different temperature $\left(\mathrm{a}:-2^{\circ} \mathrm{C}, \mathrm{b}:+3^{\circ} \mathrm{C}\right)$ and precipitation $(\mathrm{c}:+50 \%$, $\mathrm{d}$ : $-50 \%)$ perturbations .
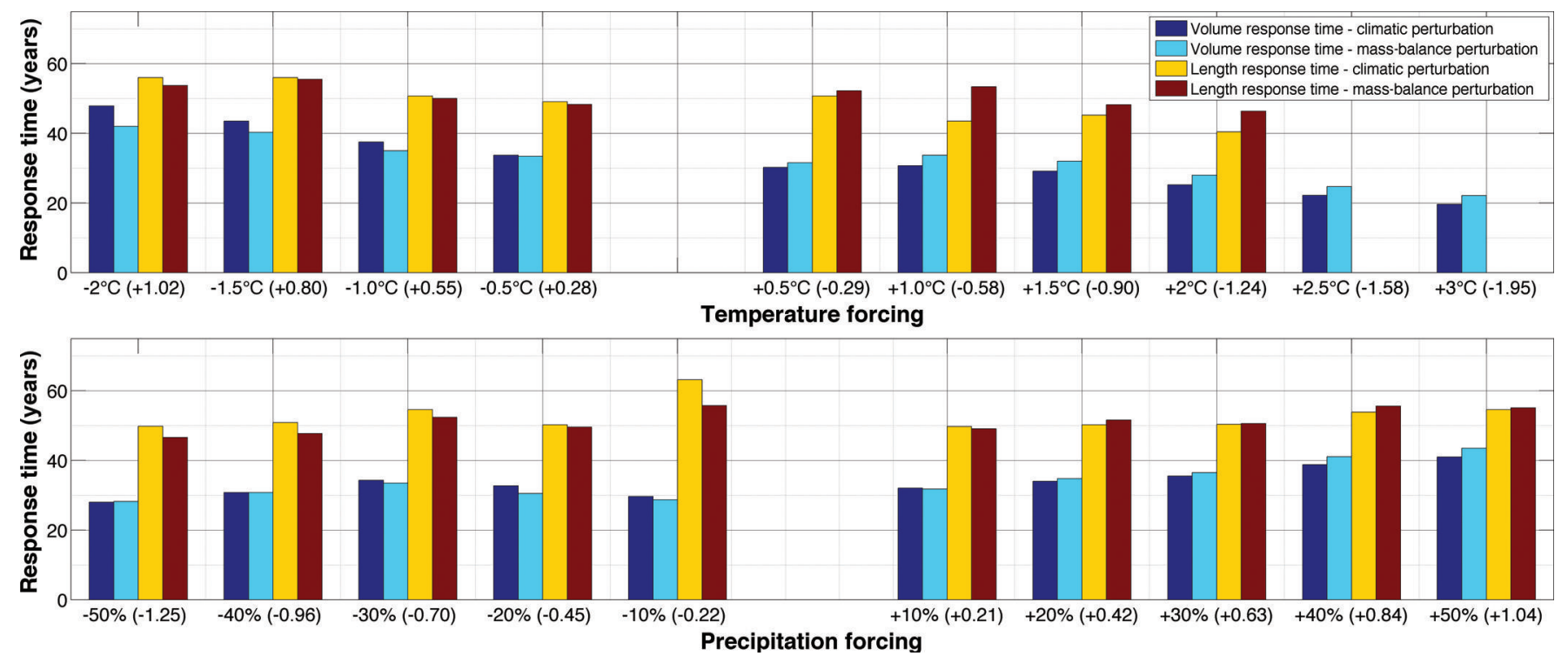

Fig. 7. Volume and length response times for different climatic perturbations. The corresponding average mass-balance perturbation is given in parentheses. For the two most positive temperature perturbations the length response time could not be determined, as the glacier disintegrates into separate ice patches during its retreat. The simulations start from a steady state with the same length as the present-day glacier, obtained by applying a $+0.5 \mathrm{~m}$ w.e. $\mathrm{a}^{-1}$ mass-balance bias on top of the average 1983-2012 climate. This bias is maintained during the simulations. 
thickness of $\sim 360 \mathrm{~m}$ for the steady-state glacier with present-day length arises from a local bedrock overdeepening. Using the maximum ice thickness as characteristic ice thickness and using a frontal mass-balance rate of $-6.3 \mathrm{~m}$ ice eq. $\mathrm{a}^{-1}$ (value for steady-state glacier with present-day length and corresponding forcing) yields a volume response time of 57 years. As the maximum ice thickness results from an irregularity in the bedrock, it is more appropriate to opt for the average ice thickness along the main flowline $(177 \mathrm{~m})$, which is also close to the ice thickness around the equilibrium line. This results in response times between 20.6 and 35.8 years, slightly lower than those obtained from our numerical simulations (Fig. 8, dark blue). An alternative approach is to define the characteristic ice thickness as the change in volume divided by the change in area for a specific glacier change (Harrison and others, 2001). For our numerical steady-state simulations this results in a characteristic ice thickness between 134 (-2.0 m w.e. $\mathrm{a}^{-1}$ forcing) and $215 \mathrm{~m} \mathrm{(+1.25} \mathrm{m} \mathrm{w.e.} \mathrm{a}^{-1}$ forcing). Calculating $T_{\mathrm{e}, \text { Jóh with }}$ this characteristic ice thickness leads to response times that are in good agreement with the numerical values (Fig. 8, light blue).The Jóhannesson method is known to provide a good estimate for the volume response time of steep glaciers, but underestimates it when the glacier is flatter and the importance of the elevation mass-balance feedback increases (Oerlemans, 1989, 2001; Harrison and others, 2001, 2003). This is also clear from our simulations, where the main disagreement with the response time from numerical simulations occurs for strong advances, where, due to the flat glacier forefield, the mass-balance elevation feedback becomes important. An approach by which to take the elevation mass-balance feedback into account is proposed by Harrison and others (2001) who introduce the areaaveraged specific balance rate gradient $\left(b_{\text {grad,av }}\right)$. In their response-time definition:

$$
T_{\mathrm{e}, \mathrm{Har}}=\frac{H_{\text {char }}}{-b_{\text {exp } / \text { cov }}-\left(b_{\text {grad, av }}\right) H_{\text {char }}}
$$

where $b_{\text {exp/cov }}$ is the average balance rate over the exposed/ covered region, close to the balance rate at the snout. The best agreement with the numerical simulations is obtained with the average ice thickness (Fig. 8, orange), while the volume-area thickness scale (proposed in their method) generally leads to overestimations (Fig. 8, red). This result was also found by Leysinger Vieli and Gudmundsson (2004) who obtained an overestimation with this method by using the volume-area thickness scale, but a good fit when using the average ice thickness. Their finding for an idealized glacier set-up can thus be confirmed here for a real alpine glacier. The overestimation results from the fact that the volume-area thickness scale takes into account the massbalance feedback implicitly, as it increases together with the feedback. When using the volume-area thickness scale to calculate $T_{\mathrm{e}, \mathrm{Har}}$ the mass-balance elevation feedback is then taken into account twice.

Oerlemans (2001) gives an expression for the response time based on the ratio between a length and velocity scale, which for an idealized glacier geometry reads (Oerlemans, 2012)

$$
T_{\mathrm{e}, \text { Oer }}=\frac{c}{\beta_{s} s \sqrt{(1+20 s) L}}
$$

Here $\beta$ is the mass-balance gradient, $s$ is the mean surface slope and $L$ is the equilibrium length; $c$ is a constant obtained from detailed numerical simulations of 15 glaciers and has a value $19.4 \mathrm{~m}^{3 / 2}$ (Leclercq and Oerlemans, 2012). For steady-state Morteratsch glacier with present-day length $\left(\beta=-0.0085 \mathrm{a}^{-1}, s=0.33, L=6.3 \mathrm{~km}\right)$ this results in a response timescale of 32 years, in the middle of the range obtained by our numerical simulations.

Another analytical method accounting for the glacier geometry is proposed by Raper and Braithwaite (2009) using a simple model for glacier hypsometry. They derive an expression for the volume response time equal to $T_{\mathrm{e}, \text { Jóh }}$ divided by an altitude-range area scaling parameter. This parameter typically varies between 0.3 and 0.4 . Applying this scale to Morteratsch glacier results in a volume response time between 55 and 110 years for a retreat, and 80 and 140 years for an advance, considerably higher than those found from our numerical simulations.

\subsubsection{Response time of Vadret da Morteratsch reported in the literature}

Two other estimates of the response time of Morteratsch glacier have been reported previously (Oerlemans, 2007, 2012). In a first approach Oerlemans (2007) used the length record of Morteratsch glacier and nearby Palü glacier. The assumption is made that neighbouring glaciers are subject to the same climatic forcing and that the differences in their length record must therefore result from differences in climatic sensitivity and response time. A volume response time of 33 years is obtained for Morteratsch glacier, which is situated in the middle of the range from our numerical simulations. Oerlemans (2007) found that the climate sensitivity of Morteratsch glacier equals $-17.7 \mathrm{~m} \mathrm{~m}^{-1}$, meaning that the glacier retreats by $1770 \mathrm{~m}$ for a $100 \mathrm{~m}$ increase in ELA. We obtain a very similar sensitivity from our numerical simulations, in which for the present-day steadystate glacier $\mathrm{a}-0.5 \mathrm{~m}$ w.e. $\mathrm{a}^{-1}$ forcing $(71 \mathrm{~m}$ ELA rise) leads to $1375 \mathrm{~m}$ of retreat, and a forcing of $-0.75 \mathrm{~m}$ w.e. $\mathrm{a}^{-1}(108 \mathrm{~m}$ ELA rise) results in $1950 \mathrm{~m}$ of retreat. In a more recent publication, Oerlemans (2012) mentions a response time of 38 years for Vadret da Morteratsch, based on a numerical SIA simulation with a 3-D geometry parameterization (Oerlemans, 1997). This value is at the higher end of our range and may indicate an overestimation due to the use of the SIA, although this is difficult to verify as the model set-up and parameters are very different.

\section{GLACIER RESPONSE TIME IN A CHANGING CLIMATE}

So far the response time has been analysed for the presentday glacier size. Here we analyse the effect of the glacier size by forcing glaciers of different sizes obtained from the earlier response-time experiments (Section 5.1) with -0.5 and $+0.5 \mathrm{~m}$ w.e. $\mathrm{a}^{-1}$ perturbations (Table 1 ). These are all steady-state glaciers situated in the same topographic setting as the present-day glacier.

The smallest glacier $\left(7.3 \mathrm{~km}^{2}\right)$ has the shortest response time (Table 1), but for the others there is no clear correlation between the glacier size and response time. For a given perturbation a larger glacier will undergo a larger volume and length change, but the higher flow velocities will compensate for this in terms of response time. A different way to analyse this is from the Jóhannesson or Harrison response time perspective: larger glaciers are thicker (numerator of Eqns (1) and (2)), but reach lower altitudes 


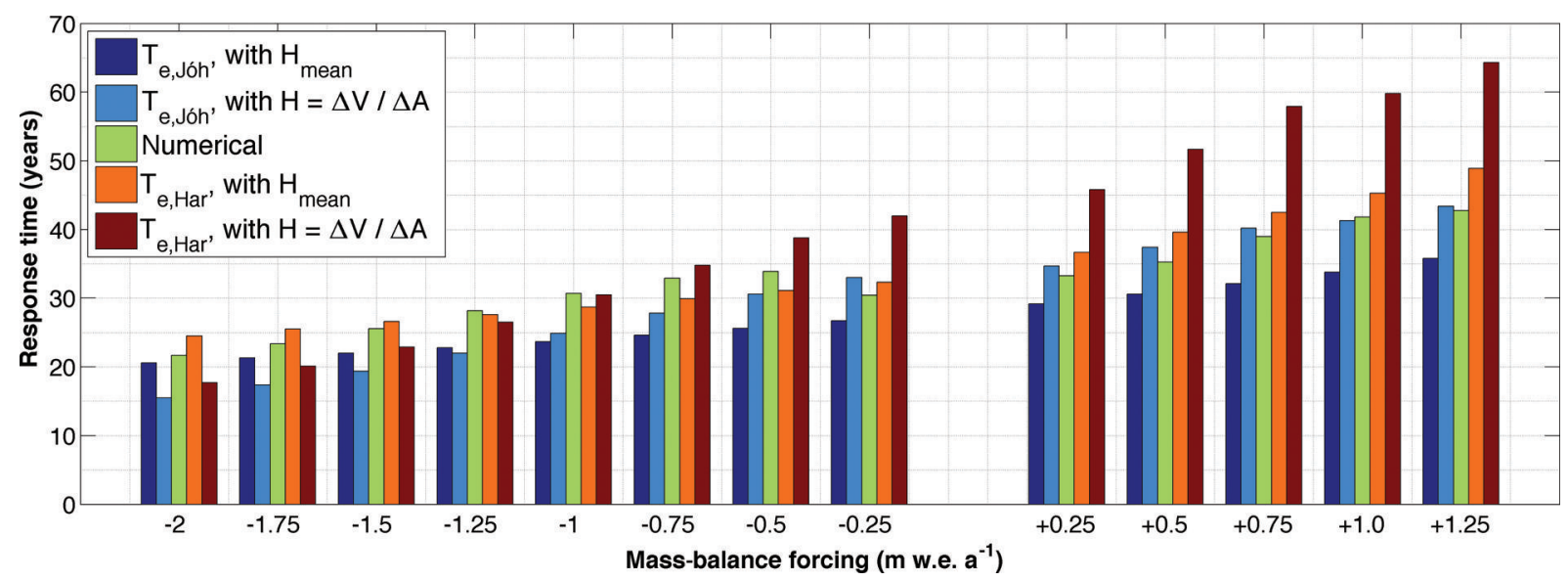

Fig. 8. Numerical and analytical response times for different mass-balance perturbations. The simulations start from a steady state with the same length as the present-day glacier, obtained by applying a $+0.5 \mathrm{~m}$ w.e. $\mathrm{a}^{-1}$ mass-balance bias on top of the average $1983-2012$ climate. This bias is maintained during the simulations.

and thus have a large frontal ablation (denominator of Eqns (1) and (2)). Yet another way to interpret this is from the Oerlemans response-time formulation (Eqn (3)): for an extending glacier (larger $L$ ) the surface slope reduces (smaller $s)$ as Morteratsch glacier extends into flatter terrain. $\tau_{\text {Oer }}$ response times are close to the response times from the numerical model (Table 1), reproduce the increase in response time with size for the smallest glaciers (7.3$16.6 \mathrm{~km}^{2}$ ) and mimic the fact that this is not the case for the largest glaciers $\left(16.6-23.6 \mathrm{~km}^{2}\right)$. The variations in response time between an advance and retreat are mainly related to the bedrock topography and are thus site-specific. A clear example of this is the advancing $11.9 \mathrm{~km}^{2}$ glacier, which has the longest response time. Here the large bedrock depression that corresponds to the present-day high ice thickness area of Vadret da Morteratsch fills up in the vicinity of the front during the glacier's advance. This process takes a considerable amount of time and causes a large volume change.

In a warming climate Morteratsch glacier will shrink and its response time will thus decrease. This relates to a steepening of the glacier. Furthermore, as temperature rises, more surface melting is expected, which can enhance glacier flow by increased basal sliding and further reduce the glacier's response time. Some basic sensitivity experiments were performed which indicate a correlation between the response time and the flow parameters (not shown here). This effect is not explicitly taken into account in analytical methods, but may be of importance when comparing different glacier response times on a global scale.

\section{VOLUME-AREA RELATIONSHIP}

The steady-state geometries obtained from the previous experiments are used to investigate the relationship between glacier volume and area. This relationship is commonly expressed through volume-area $(V-A)$ scaling, which is the most widely used method to determine the volume of a large sample of glaciers, estimating the volume of individual glaciers as (Macheret and others, 1988; Bahr and others 1997)

$$
V=c A^{\gamma}
$$

where $c$ is the power-law coefficient and $\gamma$ the exponent. We use 14 different steady states, with different sizes obtained from the mass-balance perturbation experiments (Section 5.1), to test this method (Fig. 9a). Five commonly used sets of parameters from the literature provide a reasonable fit to our glacier geometries $\left(0.76<R^{2}<0.91\right.$,

Table 1. Volume and length response times for steady-state glaciers of different sizes. The retreat experiment corresponds to an instantaneous mass-balance forcing of $-0.5 \mathrm{~m}$ w.e. $\mathrm{a}^{-1}$, and the advance experiment corresponds to an instantaneous mass-balance forcing of +0.5 m w.e. $a^{-1}$

\begin{tabular}{|c|c|c|c|c|c|c|c|c|}
\hline $\begin{array}{l}\text { Glacier } \\
\text { length }\end{array}$ & $\begin{array}{l}\text { Maximum } \\
\text { ice thickness }\end{array}$ & $\begin{array}{l}\text { Glacier } \\
\text { area }\end{array}$ & $\begin{array}{l}\text { Mean } \\
\text { surface slope }\end{array}$ & $\begin{array}{l}\text { Obtained from a mass balance forcing of } \\
\text { (vs steady state with present-day length) }\end{array}$ & & $\begin{array}{l}\text { Volume } \\
\text { response time }\end{array}$ & $\begin{array}{l}\text { Length } \\
\text { response time }\end{array}$ & $\tau_{\text {Oer }}$ \\
\hline $\mathrm{km}$ & $\mathrm{m}$ & $\mathrm{km}^{2}$ & & m w.e. $a^{-1}$ & & years & years & years \\
\hline 2.9 & 147 & 7.3 & 0.52 & -2 & $\begin{array}{c}\text { retreat } \\
\text { advance }\end{array}$ & $\begin{array}{l}23.2 \\
23.5\end{array}$ & $\begin{array}{l}37.7 \\
28.6\end{array}$ & 24 \\
\hline 4.1 & 178 & 11.9 & 0.44 & -1 & $\begin{array}{c}\text { retreat } \\
\text { advance }\end{array}$ & $\begin{array}{l}20.7 \\
43.8\end{array}$ & $\begin{array}{l}35.2 \\
58.4\end{array}$ & 26 \\
\hline 6.3 & 359 & 16.6 & 0.33 & 0 & $\begin{array}{c}\text { retreat } \\
\text { advance }\end{array}$ & $\begin{array}{l}33.9 \\
35.3\end{array}$ & $\begin{array}{l}51.5 \\
51.4\end{array}$ & 32 \\
\hline 7.9 & 404 & 18.8 & 0.30 & +0.5 & $\begin{array}{c}\text { retreat } \\
\text { advance }\end{array}$ & $\begin{array}{l}28.0 \\
39.5\end{array}$ & $\begin{array}{l}53.5 \\
53.2\end{array}$ & 32 \\
\hline 9.5 & 430 & 23.6 & 0.29 & +1.25 & retreat & 28.7 & 58.5 & 31 \\
\hline
\end{tabular}



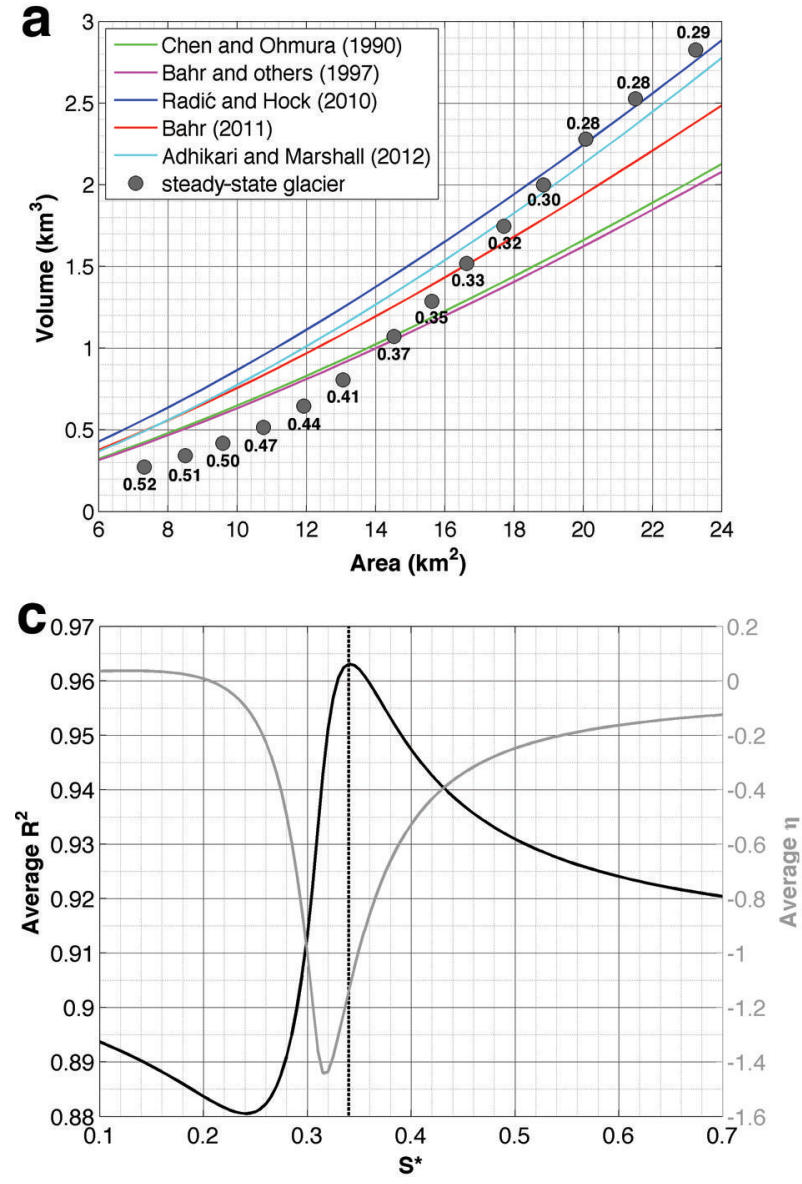
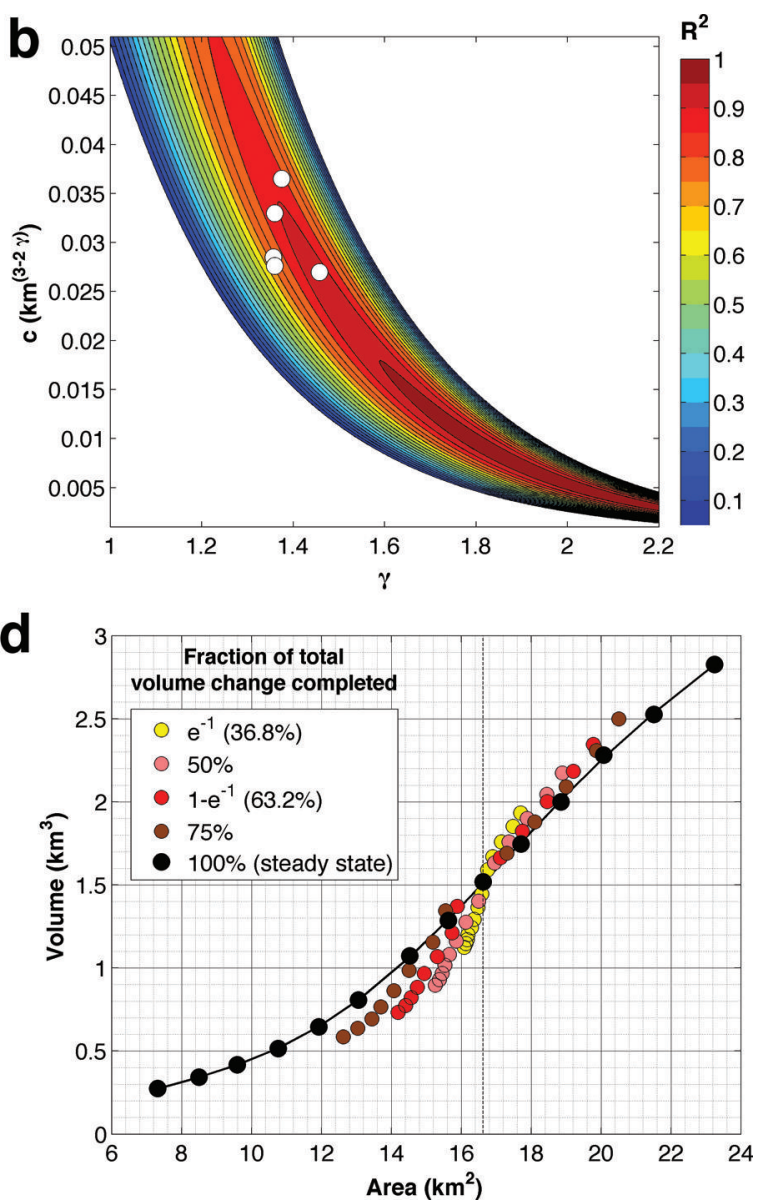

Fig. 9. (a) Glacier volume as a function of glacier area for simulated steady-state glaciers (grey dots; numbers indicate average surface slope) and commonly used $V-A$ relationships: $c=0.0285 \mathrm{~km}^{(3-2 \gamma)}, \gamma=1.357$ (Chen and Ohmura, 1990; $R^{2}=0.79$ ); $c=0.0276 \mathrm{~km}^{(3-2 \gamma)}, \gamma=1.360$ (Bahr and others (1997), $\left.R^{2}=0.76\right) ; C=0.0365 \mathrm{~km}^{(3-2 \gamma)}, \gamma=1.375$ (Radić and Hock, 2010; $R^{2}=0.87$ ); $c=0.033 \mathrm{~km}^{(3-2 \gamma)}, \gamma=1.360($ Bahr, 2011; $R^{2}=0.89$ ); $c=0.027 \mathrm{~km}^{(3-2 \gamma)}, \gamma=1.458$ (Adhikari and Marshall, 2012; $R^{2}=0.91$ ). (b) $R^{2}$ values between modelled (geometry) and predicted $\left(V-A\right.$ scaling) volume for different parameter combinations. Parameter space where the $R^{2}$ value is $<0.05$ is left blank. The white dots represent the commonly used $V-A$ relationships (see (a)). (c) Average $R^{2}$ between modelled (geometry) and predicted ( $V-A$ scaling with slope, Eqn (5)) volume for five parameter combinations (see (a)) as a function of $S^{*}$ and corresponding average $\eta$. (d) $V-A$ relationship for steady-state and transient glaciers. The starting point of the transient glaciers is a steady-state glacier with present-day length (dotted black line) and the forcing varies between -2 and $+1.25 \mathrm{~m}$ w.e. $\mathrm{a}^{-1}$.

average $R^{2}=0.84$ ) (Fig. $\left.9 \mathrm{~b}\right)$, but in all cases overestimate the volume of small glaciers and underestimate it for large glaciers. To solve for this, a steeper $V-A$ curve is needed $\left(\gamma=2.113\right.$ and $c=0.0039 \mathrm{~km}^{(3-2 \gamma)}$ provide a best fit, $R^{2}=0.993$ ) (Fig. 9b). However, with such a relationship the volume is strongly overestimated for larger glaciers. A possible way to account for this without altering $c$ and $\gamma$ is by including the average surface slope $(S)$ and a threshold slope $\left(S^{*}\right)$ to the $V-A$ scaling:

$$
V=c A^{\gamma}\left(\frac{S}{S *}\right)^{\eta}
$$

Here $\eta$ is the power-law exponent and $S^{*}$ is the threshold slope above which the scaled volume decreases compared with the classical $V-A$ scaling. For slopes below $S^{*}$ the volume increases. The physical reasoning behind this is that steep slopes (small glaciers in our experiments) translate into a lower ice thickness, while the opposite is true for gentler surface slopes (large glaciers). This inverse relationship between local surface slope and ice thickness follows from plastic flow theory (Nye, 1952) and is recurrent in most ice thickness reconstruction methods (e.g. Farinotti and others, 2009; Li and others, 2012). We evaluate Eqn (5) for five parameter combinations ( $c$ and $\gamma$ ) from the literature and find that the average $R^{2}$ between the geometries and the scaled volumes is highest for $S^{*}=0.34$ (average $R^{2}=0.963$ ), for which the average $\eta$ equals -1.14 (Fig. 9c). With this exponent, halving the surface slope results in a scaled volume multiplication with a factor $2.2\left(0.5^{-1.14}\right)$, which is close to the inverse relationship (factor $2,0.5^{-1}$ ) expected between surface slope and ice thickness for plastic flow.

The $V-A$ relationship for transient glacier geometries differs from steady-state geometries as the volume of an ice mass reacts faster to a perturbation than its area (Adhikari and Marshall, 2012). As a consequence, the volume of a retreating (advancing) glacier is smaller (larger) than for an equal-sized steady-state glacier. The effect of the transient state on the $V-A$ relationship is analysed for the eight retreat experiments (forcing between -0.25 and -2.0 mw.e. $\mathrm{a}^{-1}$ ) and the five advance experiments (forcing between +0.25 and $+1.25 \mathrm{mw}$.e. $\mathrm{a}^{-1}$ ) starting from a glacier with the present-day length (Section 5.1) (Fig. 9d). For advancing glaciers the difference between the transient and steadystate volumes, the 'volume disequilibrium', is rather limited and is largest (up to $7 \%$ on average) early in the evolution, when about a fraction $\mathrm{e}^{-1}$ of the total volume change has 
occurred. This is in contrast to retreating glaciers where the volume disequilibrium increases with time and is largest ( $17 \%$ on average) around the e-folding volume response time of the glacier. This indicates that the volume disequilibrium is driven mainly by the initial terminus response time of the glacier (shorter for an advancing glacier) rather than by its e-folding response volume time (longer for an advancing glacier).

\section{CONCLUSION}

Vadret da Morteratsch has retreated continuously since the end of the LIA, but the imbalance between the glacier geometry and the contemporary climate has never been larger than at present. This implies that, over recent decades, temperatures have risen faster than the geometry was able to adapt to the ongoing warming. The present-day climategeometry disequilibrium fully determines the glacier's length evolution in the coming 10-15 years and influences its overall evolution in the coming decades.

Most of our findings are site-specific, but with our calibrated high-resolution model setting provide a good general insight into the response time of a medium-sized alpine glacier. The response time of the glacier was analysed from different perspectives, both for transient and steadystate geometries, and is $\sim 30$ years for volume and 50 years for length. We project that these response times will reduce in the future, mainly due to a steepening of the glacier surface, rather than from the reduction in glacier size. Several simple analytical methods provide response times that are in good agreement with those derived from our numerical model, although there is a strong dependence on the chosen characteristic ice thickness scale.

Our experiments stress the importance of the magnitude of the forcing on the response time. However, the effect of the magnitude of the perturbation depends strongly on the glacier's volume-elevation distribution and bedrock topography. Additionally, a mass-balance forcing associated with a temperature or precipitation change has a spatial pattern, the effects of which hitherto had not been investigated. For a temperature forcing, the length response time typically differs $\sim 5 \%$ from a uniform mass-balance forcing of the same average magnitude, while for volume response times this is $\sim 10 \%$. The effect of the forcing's magnitude through bedrock topography and the volume-elevation distribution as well as the spatial pattern should be studied further in an idealized glacier set-up and accounted for in response-time parameterizations.

$V-A$ scaling was tested for a set of steady-state glaciers and we found that the inclusion of the surface slope and a threshold value were of great benefit to improve the fit. The physical reasoning behind this is that the local surface slope is related to the ice thickness (and thus volume). It will be interesting to test whether this relationship can be tuned and incorporated for a larger sample of glaciers with different topographic and climatic configurations.

Finally, we examined the difference in volume between steady-state geometries and transient glaciers and found that the difference is particularly strong for retreating glaciers. For a medium-sized alpine glacier that was close to steady state in the first half of the 1980s and has since been exposed to a mass-balance forcing between -0.5 and -0.75 m w.e. $a^{-1}$, we infer that the present-day volume will be of the order of $10-20 \%$ smaller than the steady-state volume.

\section{ACKNOWLEDGEMENTS}

We are grateful to MeteoSwiss for providing the meteorological data from Segl Maria and Samedan. The comments and suggestions of two anonymous reviewers and G. Leysinger Vieli helped improve the manuscript greatly. Harry Zekollari holds a PhD fellowship of the Research Foundation - Flanders (FWO-Vlaanderen).

\section{REFERENCES}

Adhikari S and Marshall SJ (2012) Glacier volume-area relation for high-order mechanics and transient glacier states. Geophys. Res. Lett., 39(16), L16505 (doi: 10.1029/2012GL052712)

Adhikari S, Marshall SJ and Huybrechts P (2011) On characteristic timescales of Glacier AX010 in the Nepalese Himalaya. Bull. Glaciol. Res., 29, 19-29 (doi: 10.5331/bgr.29.19)

Bahr DB (2011) Estimation of glacier volume and volume change by scaling methods. In Singh VP, Singh P and Haritashya UK eds Encyclopedia of snow, ice and glaciers. Springer, Dordrecht

Bahr DB, Meier MF and Peckham SD (1997) The physical basis of glacier volume-area scaling. J. Geophys. Res., 102(B9), 20 355-20362 (doi: 10.1029/97JB01696)

Bahr DB, Dyurgerov M and Meier MF (2009) Sea-level rise from glaciers and ice caps: a lower bound. Geophys. Res. Lett., 36(3), L03501 (doi: 10.1029/2008GL036309)

Berthier E and Vincent C (2012) Relative contribution of surface mass-balance and ice-flux changes to the accelerated thinning of the Mer de Glace, French Alps, over 1979-2008. J. Glaciol., 58(209), 501-512 (doi: 10.3189/2012JoG11J083)

Blatter H (1995) Velocity and stress fields in grounded glaciers: a simple algorithm for including deviatoric stress gradients. J. Glaciol., 41(138), 333-344

Chen J and Ohmura A (1990) Estimation of Alpine glacier water resources and their change since the 1870s. IAHS Publ. 193 (Symposium at Lausanne 1990 - Hydrology in Mountainous Regions), 127-135

Church JA and 13 others (2013) Sea level change. In Stocker TF and 9 others eds Climate change 2013: the physical science basis. Contribution of Working Group I to the Fifth Assessment Report of the Intergovernmental Panel on Climate Change. Cambridge University Press, Cambridge

Cuffey KM and Paterson WSB (2010) The physics of glaciers, 4th edn. Butterworth-Heinemann, Oxford

Farinotti D, Huss M, Bauder A, Funk M and Truffer M (2009) A method to estimate ice volume and ice-thickness distribution of alpine glaciers. J. Glaciol., 55(191), 422-430 (doi: 10.3189/ 002214309788816759)

Fürst JJ, Rybak O, Goelzer H, De Smedt B, De Groen P and Huybrechts P (2011) Improved convergence and stability properties in a three-dimensional higher-order ice sheet model. Geosci. Model Dev., 4(4), 1133-1149 (doi: 10.5194/gmd-41133-2011)

Glaciological Reports (1881-2009) The Swiss glaciers. Yearbooks of the Cryospheric Commission of the Swiss Academy of Sciences (SCNAT), Vols1-126. Published since 1964 by VAW-ETH, Zürich http://glaciology.ethz.ch/swiss-glaciers/, 1881-2009

Glen JW (1955) The creep of polycrystalline ice. Proc. R. Soc. London, Ser. A, 228(1175), 519-538 (doi: 10.1098/rspa. 1955.0066)

Gregory JM and 17 others (2013) Twentieth-century global-mean sea level rise: is the whole greater than the sum of the parts? J. Climate, 26(13), 4476-4499 (doi: 10.1175/JCLI-D-12-00319.1)

Greuell W (1992) Hintereisferner, Austria: mass-balance reconstruction and numerical modelling of the historical length variations. J. Glaciol., 38(129), 233-244

Gudmundsson GH (2003) Transmission of basal variability to a glacier surface. J. Geophys. Res., 108(B5), 2253 (doi: 10.1029/ 2002JB0022107) 
Harrison WD, Elsberg DH, Echelmeyer KA and Krimmel RM (2001) On the characterization of glacier response by a single time-scale. J. Glaciol., 47(159), 659-664 (doi: 10.3189/ 172756501781831837)

Harrison WD, Raymond CF, Echelmeyer KA and Krimmel RM (2003) A macroscopic approach to glacier dynamics. J. Glaciol., 49(164), 13-21 (doi: 10.3189/172756503781830917)

Hoelzle M, Haeberli W, Dischl M and Peschke W (2003) Secular glacier mass balances derived from cumulative glacier length changes. Global Planet. Change, 36(4), 295-306 (doi: 10.1016/ S0921-8181(02)00223-0)

Huybrechts P, De Nooze P and Decleir H (1989) Numerical modelling of Glacier d'Argentière and its historic front variations. In Oerlemans J ed. Glacier fluctuations and climatic change. Kluwer Academic, Dordrecht, 373-389

Jóhannesson T, Raymond CF and Waddington ED (1989) A simple method for determining the response time of glaciers. In Oerlemans J ed. Glacier fluctuations and climatic change: proceedings of the Symposium on Glacier Fluctuations and Climatic Change, 1-5 June 1987, Amsterdam, The Netherlands. (Glaciology and Quaternary Geology 6) Kluwer Academic, Dordrecht, 343-352

Jouvet G, Huss M, Blatter H, Picasso M and Rappaz J (2009) Numerical simulation of Rhonegletscher from 1874 to 2100. J. Comput. Phys., 228(17), 6426-6439 (doi: 10.1016/j.jcp.2009. 05.033)

Jouvet G, Huss M, Funk M and Blatter H (2011) Modelling the retreat of Grosser Aletschgletscher, Switzerland, in a changing climate. J. Glaciol., 57(206), 1033-1045 (doi: 10.3189/ 002214311798843359)

Leclercq PW and Oerlemans J (2012) Global and hemispheric temperature reconstruction from glacier length fluctuations. Climate Dyn., 38(5-6), 1065-1079 (doi: 10.1007/s00382-0111145-7)

Leysinger Vieli GJMC and Gudmundsson GH (2004) On estimating length fluctuations of glaciers caused by changes in climatic forcing. J. Geophys. Res., 109(F1), F01007 (doi: 10.1029/ 2003JF000027)

Li H, Ng F, Li Z, Qin D and Cheng G (2012) An extended 'perfectplasticity' method for estimating ice thickness along the flow line of mountain glaciers. J. Geophys. Res., 117(F1), F01020 (doi: 10.1029/2011JF002104)

Macheret YuYa, Cherkasov PA and Bobrova LI (1988) Tolshchina i ob'yem lednikov Dzhungarskogo Alatau po dannym aeroradiozondirovaniya [The thickness and volume of Dzhungarskiy Alatau glaciers from airborne radio echo- sounding data]. Mater. Glyatsiol. Issled., 62, 59-70

Maisch M, Burga CA and Fitze P (1999) Lebendiges Gletschervorfeld: von schwindenden Eisströmen, schuttreichen Moränenwällen und wagemutigen Pionierplflanzen im Vorfeld des Morteratschgletschers. Engadin Press, Samedan

Marzeion B, Jarosch AH and Gregory JM (2014) Feedbacks and mechanisms affecting the global sensitivity of glaciers to climate change. Cryosphere, 8(1), 59-71 (doi: 10.5194/tc-8-59-2014)

Nemec J, Huybrechts P, Rybak O and Oerlemans J (2009) Reconstruction of the annual balance of Vadret da Morteratsch, Switzerland, since 1865. Ann. Glaciol., 50(50), 126-134 (doi: 10.3189/172756409787769609)

Nye JF (1952) The mechanics of glacier flow. J. Glaciol., 2(12), 82-93

Nye JF (1957) The distribution of stress and velocity in glaciers and ice-sheets. Proc. R. Soc. London, Ser. A, 239(1216), 113-133 (doi: 10.1098/rspa.1957.0026)

Nye JF (1960) The response of glaciers and ice-sheets to seasonal and climatic changes. Proc. R. Soc. London, Ser. A, 256(1287), 559-584 (doi: 10.1098/rspa.1960.0127)
Nye JF (1965) The frequency reponse of glaciers. J. Glaciol., 5(41), $567-587$

Oerlemans J (1988) Simulation of historic glacier variations with a simple climate-glacier model. J. Glaciol., 34(118), 333-341

Oerlemans J (1989) On the response of valley glaciers to climatic change. In Oerlemans J ed. Glacier fluctuations and climatic change. Kluwer Academic, Dordrecht, 353-371

Oerlemans J (1997) A flowline model for Nigardsbreen, Norway: projection of future glacier length based on dynamic calibration with the historic record. Ann. Glaciol., 24, 382-389

Oerlemans J (2001) Glaciers and climate change. AA Balkema, Lisse

Oerlemans J (2007) Estimating response times of Vadret da Morteratsch, Vadret da Palü, Briksdalsbreen and Nigardsbreen from their length records. J. Glaciol., 53(182), 357-362 (doi: $10.3189 / 002214307783258387$ )

Oerlemans J (2012) Linear modelling of glacier length fluctuations. Geogr. Ann. A, 94(2), 183-194 (doi: 10.1111/j.1468-0459. 2012.00469.x)

Oerlemans J and 10 others (1998) Modelling the response of glaciers to climate warming. Climate Dyn., 14(4), 267-274 (doi: 10.1007/s003820050222)

Oerlemans J, Giesen RH and Van den Broeke MR (2009) Retreating alpine glaciers: increased melt rates due to accumulation of dust (Vadret da Morterastch, Switzerland). J. Glaciol., 55(192), 729-736 (doi: 10.3189/002214309789470969)

Pattyn F (2003) A new three-dimensional higher-order thermomechanical ice-sheet model: basic sensitivity, ice stream development, and ice flow across subglacial lakes. J. Geophys. Res., 108(B8), 2382 (doi: 10.1029/2002JB002329)

Pelto MS and Hedlund C (2001) Terminus behavior and response time of North Cascade glaciers, Washington, U.S.A. J. Glaciol., 47(158), 497-506 (doi: 10.3189/172756501781832098)

Radić V and Hock R (2010) Regional and global volumes of glaciers derived from statistical upscaling of glacier inventory data. J. Geophys. Res., 115(F1), F01010 (doi: 10.1029/2009JF001373)

Raper SCB and Braithwaite RJ (2009) Glacier volume response time and its links to climate and topography based on a conceptual model of glacier hypsometry. Cryosphere, 3(2), 183-194 (doi: 10.5194/tc-3-183-2009)

Raymond CF, Waddington ED and Jøhannesson T (1990) Changes in glacier length induced by climate changes (Abstract). Ann. Glaciol., 14, 355

Schwitter MP and Raymond CF (1993) Changes in the longitudinal profiles of glaciers during advance and retreat. J. Glaciol., 39(133), 582-590

Van der Veen CJ and Whillans IM (1989) Force budget: I. Theory and numerical methods. J. Glaciol., 35(119), 53-60 (doi: 10.3189/002214389793701581)

Van de Wal RSW and Oerlemans J (1995) Response of valley glaciers to climate change and kinematic waves: a study with a numerical ice-flow model. J. Glaciol., 41(137), 142-152

Weertman J (1964) The theory of glacier sliding. J. Glaciol., 5(39), 287-303

Zekollari H, Huybrechts P, Fürst J, Rybak J and Eisen O (2013) Calibration of a higher-order 3-D ice-flow model of the Morteratsch glacier complex, Engadin, Switzerland. Ann. Glaciol., 54(63 Pt 2), 343-351 (doi: 10.3189/2013AoG63A434)

Zekollari H, Fürst JJ and Huybrechts P (2014) Modelling the evolution of Vadret da Morteratsch, Switzerland, since the Little Ice Age and into the future. J. Glaciol., 60(224), 1155-1168 (doi: 10.3189/2014JoG14J053)

Zuo Z and Oerlemans J (1997) Contribution of glacier melt to sealevel rise since AD 1865: a regionally differentiated calculation. Climate Dyn., 13, 835-845 